\title{
Investigation of the Qaqarssuk carbonatite complex, southern West Greenland
}

\author{
Christian Knudsen
}

During the summer of 1984 the Qaqarssuk carbonatite complex was visited as a part of the EEC supported project 'Apatite Mineralisations in Carbonatite and Ultramafic Intrusions in Greenland'. The complex is situated $60 \mathrm{~km}$ east of Sukkertoppen and was originally found and mapped by Kryolitselskabet Øresund A/S (Vuotovesi, 1974, and Gothenborg et al., 1977).

The field work in 1984 was focussed on geological mapping of the complex (on 1: 10000 orthophoto map), and on geophysical mapping of the thickness of the overburden (described by Kjærgaard \& Olsen, this report). Collection of soil samples was carried out in order to evaluate a possible residual soil cover as a source for phosphorous and niobium. Apatite and REE mineralised rocks were also sampled for beneficiation studies.

\section{Geological setting}

The Archaean basement, consisting of granitic to tonalitic gneiss and amphibolite, was intruded by the carbonatite $170 \mathrm{Ma}$ ago (Larsen et al., 1983). A 5-20 m thick, north-south trending norite dyke and several minor dolerite dykes are also cut by the carbonatites.

The almost rectangular shape of the complex (fig. 9) is controlled by the regional fracture systems: $040-050^{\circ}$ and $130-150^{\circ}$. The carbonatite intruded as steep concentric sheets varying in thickness from a few centimetres to several tens of metres. The carbonatite sheets in the central part of the complex are thicker than the outer sheets, and the sheets swell near the 'corners' of the complex. The carbonatite sheets dip steeply outwards in the major part of the area, but in the north-west part at a low altitude, the sheets dip inwards. This indicates that the carbonatite sheets are slightly curved, giving the complex an onion-like shape (fig. 10). The sheets contain varying amounts of fenite inclusions, and the carbonatitic rocks range from homogeneous, pure carbonatite sheets to carbonatite seen in a braided pattern between fenite lenses. Hence it has been necessary to use arbitrary boundaries (at $50 \%$ carbonatite) in the mapping of the complex (fig. 9).

\section{The fenite}

The carbonatite complex is surrounded by a fenite aureole, as indicated on fig. 9. The degree of fenitisation decreases away from the individual carbonatite sheets, and the most altered/fenitised rock - the fenite proper - has lost all quartz and consists of feldspar (predominantly albite), alkali amphibole and alkali pyroxene. Where the basement is extremely fenitised, or where the composition before fenitisation was mafic, the rock may be changed to ultramafic rock types such as hornblendite or glimmerite. Both the mineralogy and the texture of the fenite are totally reworked. The fenite is often foliated, with mafic and feldspathic schlieren parallel to the adjacent carbonatite sheets. 


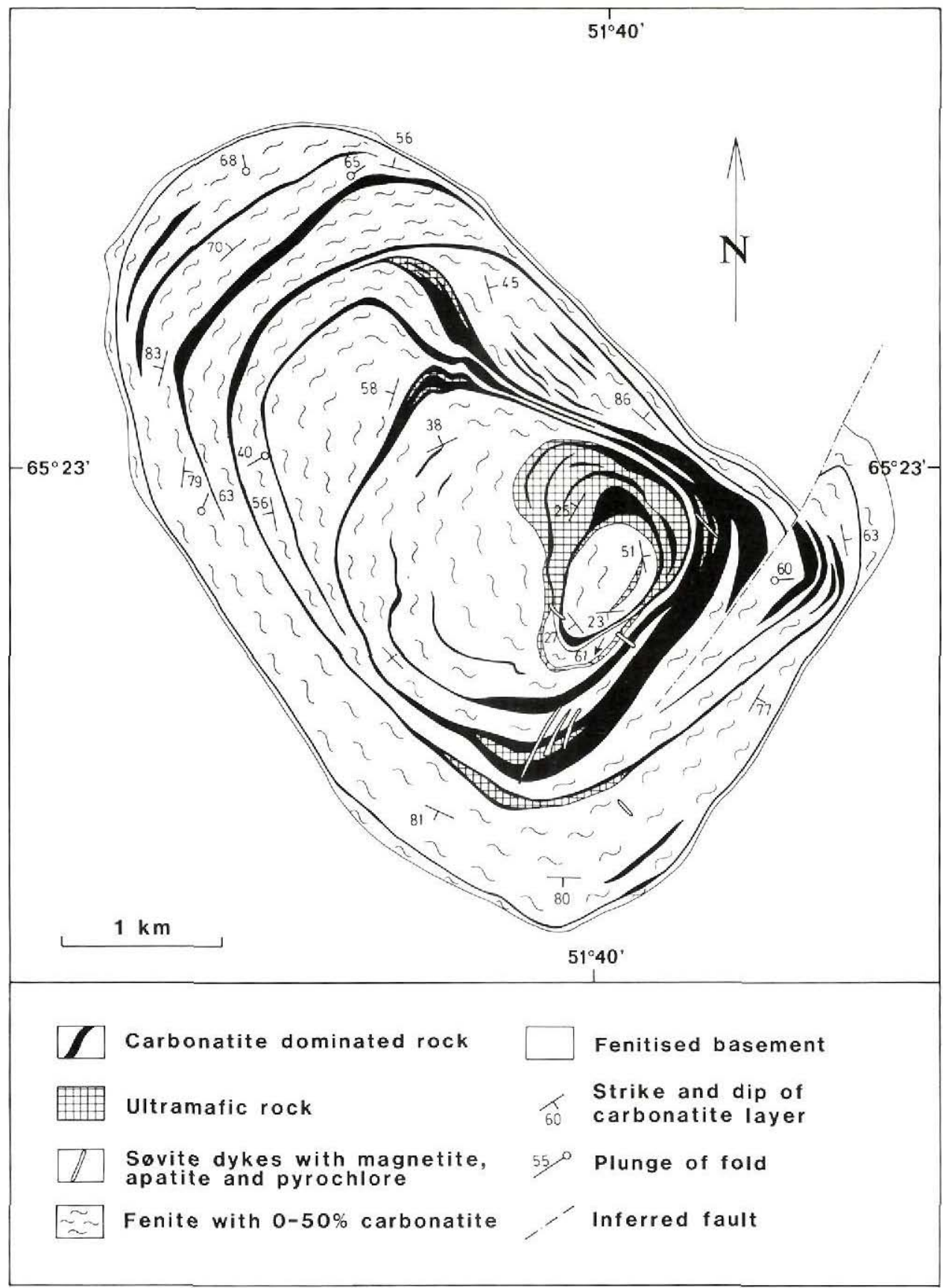

Fig. 9. Sketch map of the Qaqarssuk carbonatite. 


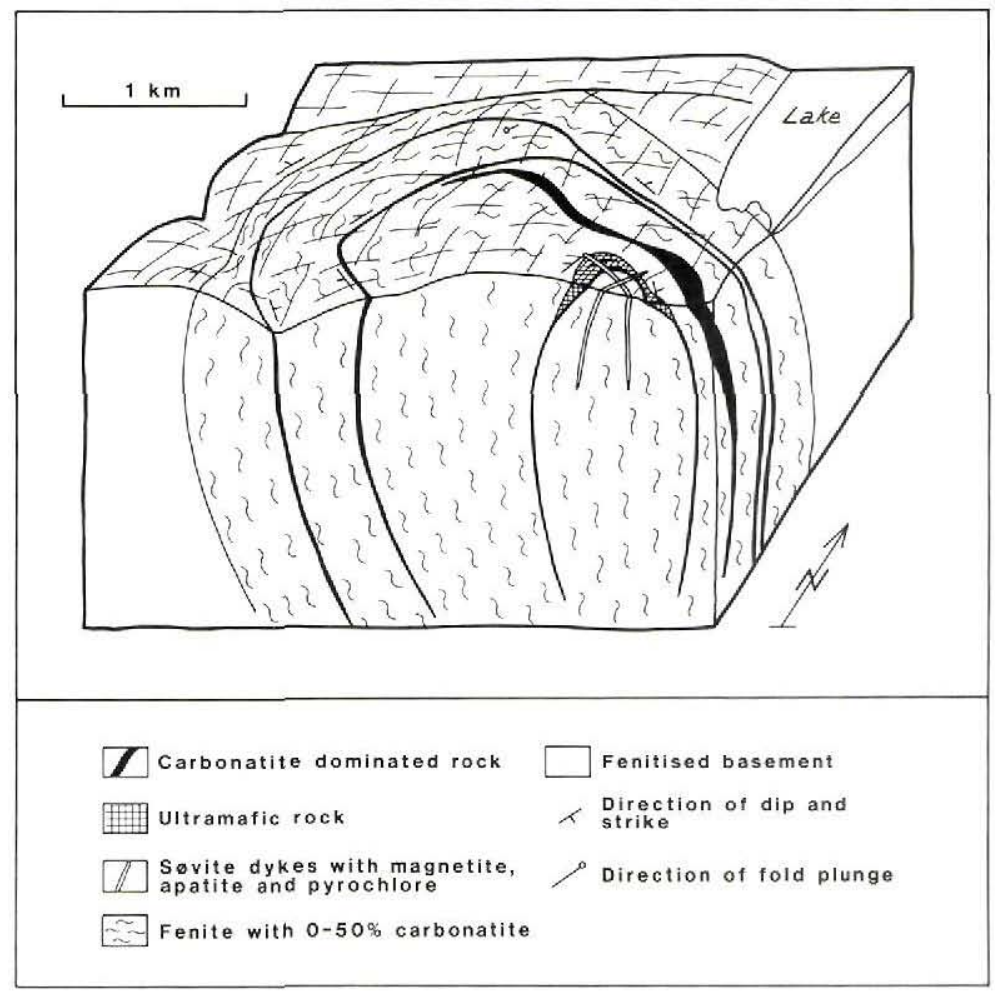

Fig. 10. Structural interpretation of the Qayarssuk carbonatite.

Away from the carbonatite sheets, the degree of fenitisation decreases and quartz appears in the felsic rocks. The most proximal quartz-bearing fenitised rocks consist of quartz, K-feldspar and alkali amphibole/pyroxene. As in the fenite proper the texture is completely reworked. The mafic minerals are mainly concentrated along joints which gives the surfaces of these rocks a greenish appearance. Further outwards there is a gradual transition into the unaltered basement. However, the degree of fenitisation does not simply decrease away from the centre of the complex. Small lenses of quartz-bearing fenitised basement rock are found inside the major carbonatite ring dykes, and more intensely fenitised rocks can be found as zones in the less altered basement rocks.

Outside the fenite there is a zone characterised by strong chloritisation and hematitisation, probably generated by hydrothermal alteration of the basement. This zone has an elevated radiation due to Th-enrichment (Secher, 1980) located in ankerite-rich veins. Calcite veins are frequent in this zone.

\section{The carbonatites}

In the field the carbonatites can be roughly divided into the following groups, based on the modal composition and texture: 
1. Calcite dominated, medium- to coarse-grained, often foliated carbonatite and silico-carbonatite (termed søvite I).

2. Dolomite dominated, medium- to coarse-grained carbonatite rich in magnetite and apatite (termed rauhaugite).

3. Dolomite dominated, fine-grained, strongly foliated and lineated carbonatite, rich in strongly deformed fenite inclusions (termed beforsite I).

4. Ankerite and dolomite dominated, fine-grained carbonatite, rich in angular inclusions of fenite and quartz-bearing fenitised basement (termed beforsite II).

5. Calcite dominated, very coarse-grained carbonatite, characterised by plate-like calcite perpendicular to the dyke margin (termed søvite II).

6. Calcite dominated, medium- to coarse-grained carbonatite with olivine and magnetite (termed olivine søvite).

7. Calcite dominated carbonatite rich in $\mathrm{REE}, \mathrm{Sr}$ and $\mathrm{Ba}$ minerals (termed REE-rich carbonatite).

Due to the concentric development of the complex it is difficult to make a relative chronology of these rock types. The only rocks with discordant relations are the søvite II dykes and the REE-rich carbonatite veins which both cut $s ø v i t e ~ I$ and the ultramafic rock types. Generally, the carbonatite becomes more fine grained and richer in $\mathrm{Mg}$ and Fe carbonates with increasing distance from the centre of the complex.

The most abundant carbonatite is the søvite I which consists of $15-40 \%$ dolomite and $5-20 \%$ apatite in a slightly more fine-grained calcite matrix $(30-70 \%)$ and up to $50 \%$ mafic minerals as biotite, phlogopite and alkali amphibole. The foliation is defined by parallel arrangement of dolomite and mafic minerals. The texture is granular with $120^{\circ}$ between grain boundaries (probably auto-metamorphic). There is a gradual transition from the pure Søvite I from silico-carbonatites to ultramafics ranging in composition from hornblendites to pyroxenite and glimmerites. The ultramafic rocks occur as layers or lenses in the carbonatites, and in the central part of the complex large ultramafic bodies with carbonatite veins and layers are found. The ultramafics are generally little foliated and the ultramafic minerals are often found in a calcite matrix.

The søvite I rocks further contain fenite inclusions with ultramafic rims (fig. 11), indicating that the ultramafics may have formed by reaction between the carbonatite and the basement rocks. On the large scale, a gradual transition is observed from the basement amphibolite to hornblende-pyroxene ultramafics and further to glimmerites. The large ultramafic bodies found near the core are interpreted as being metasomatically altered mafic basement rocks.

The silico-carbonatites are strongly deformed rocks, possibly formed by mixing of the carbonatite with silicate minerals from the deteriorating fenite inclusions as seen on fig. 11 .

The beforsite I rocks are generally highly deformed with foliation defined by deformed fenite inclusions. The foliation follows the trend of the carbonatite sheets, and fold axes and lineations in these rocks are perpendicular to the strike.

The beforsite II dykes are mainly found outside the fenites and they generally strike parallel to the margin of the complex, but in contrast they commonly dip towards the centre.

The søvite II occurs as $0.1-10 \mathrm{~cm}$ thick dykes and, apart from the plate-like calcite, are characterised by high contents of alkali amphibole, magnetite, apatite and pyrochlore, and they may carry considerable amounts of pyrrhotite. These dykes often show a cyclic layering 


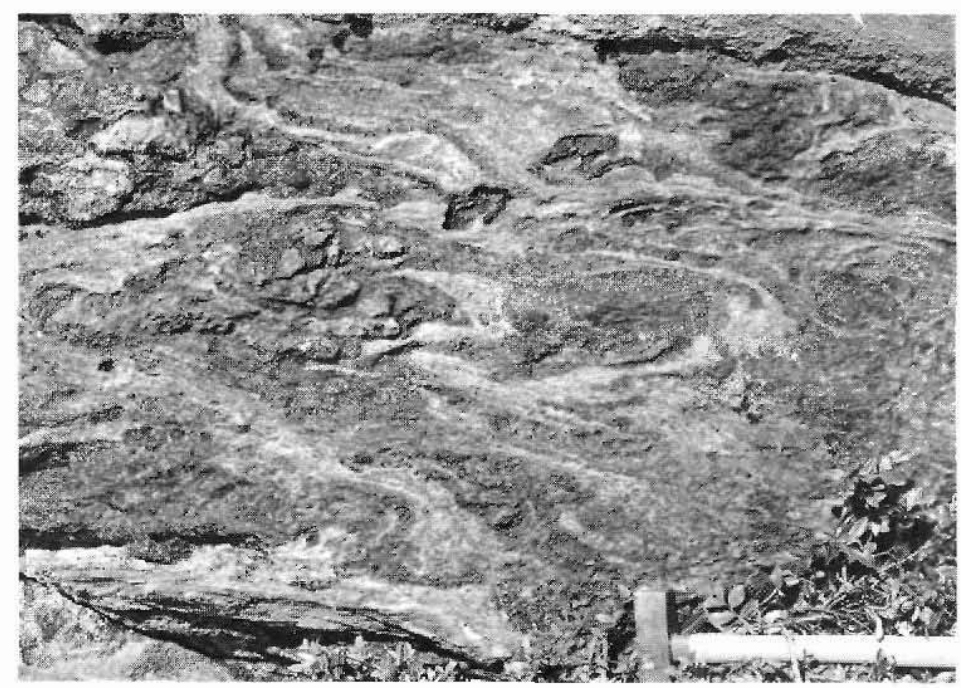

Fig. 11. Fenite inclusions with ultramafic rims in a strongly deformed silico-carbonatite.

parallel to the dyke margin, with varying proportions of phlogopite, magnetite, apatite and pyrochlore relative to calcite. In places, such dykes contain almost calcite-free layers of magnetite with apatite, alkali amphibole and pyrochlore, which are up to several metres thick.

The apatite in the søvite I, rauhaugite and beforsite is found as prismatic-more or less resorbed - crystals. On the contrary, the apatite in the søvite II dykes occurs as spherical aggregates of extremely fine-grained crystals similar to those described by Brögger (1921, p. 239) from the Fen complex. These aggregates are in places concentrated to form an almost pure apatite rock. The spherical shape and the extremely fine-grained nature of these apatite aggregates indicate that they may represent quenched droplets of apatite liquid.

The olivine søvite consists of calcite, dolomite, olivine, phlogopite, alkali amphibole and magnetite with subordinate amounts of apatite. The olivine is locally found as skeletal or hopper crystals, indicating a fast rate of crystallisation. The olivine is often resorbed or altered to a red mica (phlogopite?). Both this red mica and the magnetite are locally finely intergrown with calcite in a texture similar to what is described as symplectic intergrowth. Further magnetite is found as large poikilitic crystals.

The REE-rich carbonatite veins vary in thickness from a few millimetres up to $4 \mathrm{~m}$. They are coarse grained, miarolitic and consist of calcite, ancylite (REE \& Sr carbonate) intergrown with alstonite ( $\mathrm{Ca}$ and $\mathrm{Ba}$ carbonate), baryte, hematite and pyrrhotite. Further, chalcopyrite and galena may be seen in these veins. The sulphides are often accumulated near the margin. The REE-rich carbonatite has an elevated radiation, probably due to Th. They are generally low in $\mathrm{Nb}$, but often associated with pyrochlore and zircon mineralisation of the wall-rock. 
Fig. 12. Regolith with original layering preserved. The soil contains slightly deformed regolith clasts.

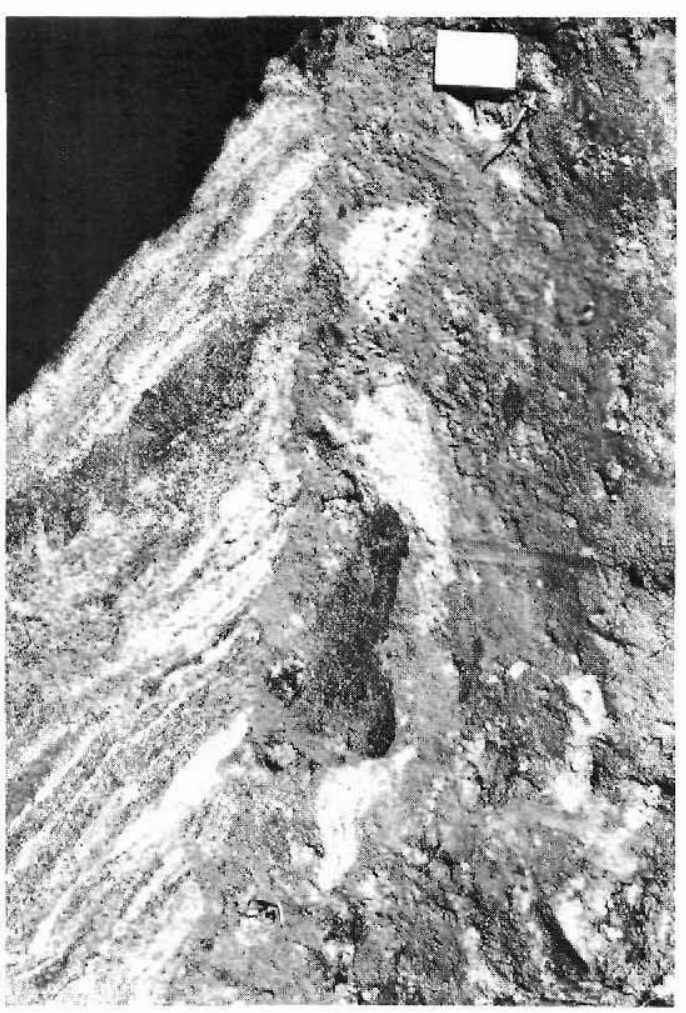

\section{Intrusive silicate rocks}

The søvite, ultramafic rocks and fenites are cut by a small number of different intrusive silicate rocks. Two occurrences of lamprophyre/kimberlite are seen as $10-100 \mathrm{~cm}$ thick dykes in the marginal parts of the complex. These dykes consist of a strongly carbonated groundmass with biotite, phlogopite and clinopyroxene, and locally with garnet xenocrysts. They contain many inclusions of fenite, pyroxenite and carbonatite. On a third locality a dyke was observed with phenocryst of black mica and large plagioclase laths.

\section{The regolith}

The exposure of the carbonatite is poor because of its relatively low resistance to weathering. Strongly weathered and soft carbonatite and ultramafic rocks were found in the valleys and even though it was possible to dig in the 'rock', the original layering was found to be preserved (fig. 12).

The weathered rock is supposed to be developed by pre-glacial weathering and protected against glacial abrasion in the lower parts of the landscape. Kunzendorf \& Secher (in press) showed that the content of $\mathrm{P}$ and $\mathrm{Nb}$ is elevated in the soil in Qaqarssuk, and this year 400 
soil samples were collected in order to: (1) find a regolith with economic contents of these elements, and (2) to trace apatite and pyrochlore-rich søvite dykes under the soil.

Acknowledgements. The field work was supported by the European Economic Community through contract number MSM-119-DK.

\title{
References
}

Brögger, W. C. 1921: Die Eruptivgesteine des Kristianiagebietes IV, Das Feugebiet in Telemarken, Norwegen. Norske Vidensk. Selsk. I, Mat. Nat. Skr. Kl. 7, 408 pp.

Gothenborg, J., Keto, L \& Pedersen, J. L., 1977: Exploration of the Qaqarssuk carbonatite complex, 1976. Kryolitselskabet Øresund A/S. Unpubl. company report.

Kunzendorf, H. \& Secher, K. in press: Dispersion of niobium and phosphorus in soil overlying the Qaqarssuk carbonatite complex, southern West Greenland. J. geochem. Explor.

Larsen, L. M., Rex, D. C. \& Secher, K. 1983: The age of carbonatites, kimberlites and lamprophyres from southern West Greenland: recurrent alkaline magmatism during 2500 million years. Lithos 16, 215-221.

Secher, K. 1980: Distribution of radioactive mineralisation in central West Greenland. Rapp. Grønlands geol. Unders. 100, 61-65.

Vuotovesi, T. 1974: [Qaqarssuk carbonatite complex.] Univ. Helsinki. Unpubl. M.Sc. thesis, 44 pp. [in Finnish].

\section{Shallow-seismic, geoelectric and magnetic investigations of the Qaqarssuk carbonatite complex, West Greenland}

\author{
Morten Kjærgaard and Kim B. Olsen
}

During the period 3rd July to 3rd September 1984 geophysical measurements were made in the Qaqarssuk area. The investigations focussed on:

(1) Shallow-seismic and geoelectric investigations of the overburden, especially its thickness.

(2) Magnetic measurements in order to refine the modelling based on existing data from Kryolitselskabet Øresund A/S (Kurki \& Juhava, 1971; Gothenborg \& Pedersen, 1976).

\section{Mapping of the overburden}

The aim of the geoelectric and seismic measurements was primarily to map the thickness of the overburden in areas where a cover of weathered rock (regolith) was expected (Knudsen, this report). On the basis of drillhole measurements in the central valley (area 1 on fig. 13), the thickness of the overburden was estimated to be about $5 \mathrm{~m}$ (Knudsen \& Secher, 1984).

The investigations were carried out mainly in two areas (fig. 13). 